\title{
PERBEDAAN PENGETAHUAN WANITA USIA SUBUR ( WUS ) TENTANG KANKER OVARIUM SEBELUM DAN SESUDAH DIBERI PENYULUHAN \\ ( Di RT 03 RT 04 Desa Sumengko Kecamatan Sukomoro Kabupaten Nganjuk )
}

Nining Istighosah ${ }^{1}$, Nurma Yunita ${ }^{2}$

${ }^{1,2}$ Akademi Kebidanan Dharma Husada Kediri Jawa Timur

\begin{abstract}
Abstrak
Kanker adalah suatu penyakit yang disebabkan oleh pertumbuhan sel - sel jaringan tubuh yang tidak normal. Sel - sel kanker akan berkembang dengan cepat, tidak terkendali, dan akan tersus membela diri . Kanker ovarium merupakan penyebab kematian terbanyak dari semua kanker ginekolog. Angka kematian yang tertinggi karena penyakit ini pada awalnya bersifat tanpa gejala dan tanpa menimbulkan keluhan apabila sudah terjadi metastasis sehingga $60-70$ persen pasien datang pada stadium lanjut. Penelitian ini merupakan penelitian pre eksperimental dengan rancangan prepost design. Populasi pada penelitian ini adalah wanita usia subur di RT 03 RW 04 Desa Sumengko Kecamatan Sukomoro Kabupaten Nganjuk dengan menggunakan teknik purposive sampling.

Hasil pada penelitian ini adalah Pengetahuan wanita usia subur tentang kanker ovarium sebelum diberikan penyuluhan menunjukan pengetahuan mayoritas masih kurang, 16 responden $(47,05 \%)$ dalam kategori cukup, dan 16 responden $(47,05 \%)$ dalam kategori kurang. Pengetahuan wanita usia subur tentang kanker ovarium setelah diberikan penyuluhan menunjukan yang baik adalah 24 responden ( 70,58\%) dalam kategori baik. Dari hasil uji statistik, diperoleh nilai $Z$ hitung sebesar 5, 41 dengan tingkat kemaknaan 0,05 dan nilai $Z$ tabel 2,045. Hal ini berarti nilai $Z$ hitung $>Z$ tabel $(5,41>2,045)$, maka ${ }_{\mathrm{H} 0}$ ditolak dan ${ }_{\mathrm{H} 1}$ diterima yang artinya ada perbedaan pengetahuan wanita usia subur tentang kanker ovarium sebelum dan sesudah diberi penyuluhan.

Simpulan dari penelitian ini adalah pentingnya peran penyuluhan kesehatan dalam meningkatkan pengetahuan, kesadaran serta perilaku kesehatan. Petugas kesehatan perlu memaksimalkan upaya dalam memberikan penyuluhan - penyuluhan kesehatan kepada wanita usia subur sehingga mempunyai pengetahuan yang baik, dan mampu mengatasi masalah kesehatannya secara mandiri .
\end{abstract}

Kata kunci : Perbedaan, Wanita Usia Subur ( WUS ), Penyuluhan

Korespondensi: Ds. Pesantren RT 009/RW 002 Kediri Jawa Timur HP: 081231352032 ,email: dealovanining@gmail.com 


\section{Pendahuluan}

Kanker adalah suatu penyakit yang disebabkan oleh pertumbuhan sel - sel jaringan tubuh yang tidak normal. Sel - sel kanker akan berkembang dengan cepat, tidak terkendali, dan akan tersus membela diri (Maharani, 2009: 11). Kanker juga merupakan salah satu penyakit yang menjadi mimpi buruk setiap orang. Diantara berbagai jenis kanker yang menyerang para wanita. Penyakit kanker terbsebut sangat berbahaya bagi kaum wanita (Maysaroh, 2013: 1). Terdapat berbagai jenis kanker di Dunia ini, kanker ovarium adalah salah satu kanker ginekologi yang paling sering dan penyebab kematian kelima akibat kanker pada perempuan.

Penyebab pasti kanker ovarium tidak diketahui namun multifaktorial. Resiko berkembangnya kanker ovarium berkaitan dengan lingkungan, endokrin, dan faktor genetik. Faktor - faktor lingkungan yang berkaitan dengan kanker ovarium terus menjadi subjek perdebatan dan penelitian. Insiden tertinggi terdapat di negara - negara industri barat. Kebiasaan makan kopi dan merokok, adanya asbestos dalam lingkungan, dan penggunaan bedak pada daerah vagina, semua itu dianggap mungkin menyebabkan kanker. Tidak ditemukan hubungan antara faktor - faktor itu dengan perkembangan kanker ovarium. Faktor risiko endokrin untuk kanker ovarium adalah perempuan yang nulipara, menarche dini, menopause yang lambat, kehamilan pertama yang lambat dan tidak pernah menyusui. Perempuan dengan kanker payudara memiliki resiko dua kali lebih besar untuk berkembangnya kanker ovarium. Penggunaan kontrasepsi oral tidak meningkatkan resiko dan mungkin dapat mencegah. Gen - gen supresor tumor seperti BRCA - 1 dan BRCA - 2 telah memperlihatkan peran penting pada beberapa keluarga. Kanker ovarium herediter yang dominan autosomal dengan variasi penetrasi telah ditunjukkan dalam keluarga yang terdapat penderita kanker ovarium. Bila terdapat dua atau lebih hubungan tingkat pertama yang menderita kanker ovarium, seorang perempuan memiliki $50 \%$ kesempatan untuk menderita kanker ovarium (Wilson, 2006: 1297).

Kanker ovarium merupakan penyebab kematian tertinggi dari kanker alat genetal perempuan. Salah satunya di USA sekitar 22.220 kasus baru didiagnosis setiap tahun, dan sekitar 16.210 kematian terjadi setiap tahun akibat penyakit ini. Kanker ovarium 6\% dari seluruh kanker pada perempuan dan penyakit ini timbul 1 orang pada setiap 68 perempuan (Prawirohardjo, 2011: 307).

Penelitian yang dilakukan dokter di University of Toronto di Kanada cukup mengejutkan. Para wanita yang positif dengan gen BRCA1 yang berisiko kanker ovarium sebaiknya mengangkat indung telurnya sebelum berusia 35 tahun. Para wanita yang masuk dalam kelompok tersebut dan memilih mengangkat indung telurnya sebanyak 80 persen mengurangi risiko kanker, dan meningkatkan kelangsungan hidup hingga 77 persen. (Liputan6.com, 2014).

Di Amerika Serikat, kanker ovarium terhitung sebagai penyebab kematian terbanyak dibandingkan dengan kanker ginekologi lainnya. Di seluruh dunia, 204.000 wanita yang terdiagnosis, 125.000 di antaranya meninggal akibat penyakit ini. Dari angka tersebut, 90 - 95 $\%$ disebabkan kanker ovarium. Sampai saat ini tidak ada metode skrining yang efektif untuk mendeteksi dini dan sedikitnya gejala dan tanda awal menyebabkan tiga perempat dari penderita datang dengan diagnosis yang sudah lanjut (Rasijidi, 2009: 183).

Di Indonesia angka kejadian kanker ovarium sebesar 30,5\% dari seluruh keganasan ginekologi yang ada. Konsultan Onkologi Ginekologi Rumah Sakit Cipto Mangunkusumo (RSCM) Prof Farid Aziz dalam seminar penanganan kanker pada sistem reproduksi perempuan, di Medan, Kamis (19/4), mengatakan, sekitar 80 persen kasus kanker ovarium yang ditemukan sudah masuk pada stadium lanjut (Republika.co.id, 2012).

Kesadaran akan pentingnya memahai apa dan bagaiana pentingnya kanker menjadi sangat penting, oleh karena itu pengenalan dan pemahaman apa saja gejala yang timbul dari penyakit kanker terutama pada alat reproduksinya. Pada kenyataannya, banyak penderita tidak menyadari bahwa dalam tubuhnya muncul kanker. Sebelum kanker meluas atau merusak jaringan disekitarnya. Oleh karena itu para wanita harus mengenal lebih jauh berbagai jenis penyakit kanker ganas yang sewaktu - waktu dapat muncul dalam tubuh. Karena penyebab dari beragam jenis penyakit kanker di Indonesia belum seluruhnya dapat dipastikan. Oleh karena itu, penting bagi para 
Nining Istighosah : Perbedaan Pengetahuan Wanita Usia Subur ( WUS ) Tentang Kanker Ovarium Sebelum Dan Sesudah Diberi Penyuluhan ( Di RT 03 RT 04 Desa Sumengko Kecamatan Sukomoro Kabupaten Nganjuk )

wanita untuk mebiasakan diri dengan program hidup sehat dengan rutin memeriksakan kesehatan, sebagai upaya untuk mencegah tumbuhnya kanker dalam tubuh anda (Setiati, 2009: 04).

Berdasarkan studi pendahuluan yang dilakukan oleh peneliti di RT 03 RW 04 Desa Sumengko Kecamatan Sukomoro Kabupaten Nganjuk terhadap 10 wanita usia subur didapatkan 3 orang $(30 \%)$ wanita usia subur mengetahui tentang kanker ovarium, dan 7 orang $(70 \%)$ wanita usia subur tidak mengetahui tentang kanker ovarium.

\section{Metode}

Penelitian ini merupakan penelitian pre eksperimental dengan rancangan pre-post design. Populasi pada penelitian ini adalah wanita usia subur di RT 03 RW 04 Desa Sumengko Kecamatan Sukomoro Kabupaten Nganjuk dengan menggunakan teknik purposive sampling.

\section{Hasil}

\section{Karakteristik Responden}

\section{1) Karakteristik Responden Berdasarkan Umur}

\begin{tabular}{ccll} 
NO & Umur ( Tahun $)$ & Frekuensi & Prosentase \\
\hline 1. & $15-25$ & 7 & 20,5 \\
\hline 2. & $26-37$ & 11 & 32,3 \\
\hline 3. & $38-39$ & 16 & 47,0 \\
\hline & Total & 34 & 100
\end{tabular}

Berdasarkan Tabel diatas dari 34 responden mayoritas wanita usia subur 16 responden
$(47,0 \%)$
berusia
38-39
tahun.

\section{2) Karakteristik Responden Berdasarkan Pendidikan}

\begin{tabular}{llll} 
NO & Pendidikan & Frekuensi & Prosentase \\
\hline 1. & Tidak tamat SD & 0 & 0 \\
\hline 2. & SD/SMP & 10 & 29,4 \\
\hline 3. & SMP/MI & 10 & 29,4 \\
\hline 4. & SMA/SMK/SMEA/MA & 12 & 35,2 \\
\hline 5. & Perguruan Tinggi & 2 & 5,8 \\
\hline & Total & & 100
\end{tabular}

Berdasarkan Tabel dari 34 responden pendidikan terakhir SMP/MI, dan 12 responden sebanyak 10 responden $(29,4 \%)$ pendidikan $\quad(35,2 \%)$ pendidikan terakhir SMA atau sederajat terakhir SD/SMP, 10 responden $(29,4 \%)$ 


\section{3) Karakteristik Responden Berdasarkan Pekerjaan}

\begin{tabular}{clll} 
NO & Pekerjaan & Frekuensi & Prosentase \\
\hline 1. & Buruh & 3 & 8,8 \\
\hline 2. & Swasta & 6 & 17,6 \\
\hline 3. & Wiraswasta & 5 & 14,7 \\
\hline 4. & PNS/ABRI & 0 & 0 \\
\hline 5 & Ibu Rumah Tangga & 20 & 58,8 \\
\hline & Total & 34 & 100
\end{tabular}

Berdasarkan Tabel dari 34 responden sebanyak 3 sebanyak 20 responden $(58,8 \%)$ bekerja sebagai responden $(8,8 \%)$ bekerja sebagai buruh, dan ibu tumah tangga. 4) Karakteristik Responden Berdasarkan Sumber Informasi

\begin{tabular}{clll} 
NO & Sumber Informasi & Frekuensi & Prosentase \\
\hline 1. & Bidan/Petugas Kesahatan Lainnya & 4 & 11,7 \\
\hline 2. & $\begin{array}{l}\text { Media Masa (Televisi, Radio, Koran, } \\
\text { Majalah) }\end{array}$ & 6 & 17,6 \\
\hline 3. & Tetangga, Teman, Saudara) & 0 & 0 \\
\hline 4. & Lain- lain & 0 & 0 \\
\hline 5 & Tidak Pernah & 24 & 70,5 \\
\hline & Total & 34 & 100
\end{tabular}

Berdasarkan Tabel dari 34 responden mayoritas responden belum pernah mendapatkan informasi sama sekali sebanyak 24 responden ( 70,58\%).

Analisa Data Perbedaan Pengetahuan Wanita Usia Subur Tentang Kanker Ovarium Sebelum Dan Sesudah Diberi Penyuluhan.

Pengetahuan Responden Sebelum Diberikan Penyuluhan

\begin{tabular}{lcclcc}
\hline \multicolumn{1}{c}{ Kategori } & Frekuensi & \% & Kategori & Frekuensi & $\%$ \\
\hline Baik & 2 & 5,88 & Baik & 24 & 70,5 \\
Cukup & 16 & 47,05 & Cukup & 8 & 23,5 \\
Kurang & 16 & 47,05 & Kurang & 2 & 5,8 \\
\hline Jumlah & 34 & 100 & Jumlah & 34 & 100 \\
& & & & & \\
\hline
\end{tabular}

Pengetahuan Responden Sesudah Diberikan Penyuluhan
Dari tabel di atas dapat dijelaskan bahwa dari 34 Perbedaan Pengetahuan Wanita Usia Subur responden terdapat perbedaan nilai antara Tentang Kanker Ovarium Sebelum dan Sesudah 
Nining Istighosah : Perbedaan Pengetahuan Wanita Usia Subur ( WUS ) Tentang Kanker Ovarium Sebelum Dan Sesudah Diberi Penyuluhan ( Di RT 03 RT 04 Desa Sumengko Kecamatan Sukomoro Kabupaten Nganjuk )

diberi Penyuluhan. Pengetahuan wanita usia subur sebelum diberi penyuluhan dengan kategori baik 2 orang $(5,88 \%), 16$ orang $(47,05 \%)$ dengan pengetahuan cukup, dan 16 orang $(47,05 \%)$ dalam kategori kurang.

\section{Diskusi}

1) Pengetahuan Wanita Usia Subur Tentang Kanker Ovarium Sebelum Diberikan Penyuluhan.

Berdasarkan tabel tabulasi diketahui bahwa pengetahuan wanita usia subur tentang kanker ovarium di RT 03 RW 04 Desa Sumengko Kec.Sukomoro Kab. Nganjuk sebelum diberikan penyuluhan sebagian besar dalam kategori kurang yaitu 16 orang $(47,05 \%)$ kategori kurang, sedangkan 2 orang ( $5,88 \%)$ pengetahuannya dalam katagori baik. Hal ini juga didukung dalam kuesioner.

Pengetahuan adalah kesan di dalam pikiran manusia sebagai hasil penggunaan pancaindranya. Pengetahuan sangat berbeda dengan kepercayaan (beliefs), takhayul, dan penerangan - penerangan yang keliru (misinformation). Pengetahuan adalah segala apa yangdiketahui berdasarkan pengalaman yang didapatkan oleh setiap manusia. Pengetahuan merupakan hasil mengingatsuatu hal, termasuk mengingat kembali kejadian yang pernah dialami baik secara sengaja maupun tidak terhadap suatu objek tertentu (Mubarak, 2011: 81).

Seseorang akan memperoleh pengetahuan dari hasil pengindaraan akan tetapi setiap orang memilii daya ingat dan daya tangkap yang berbeda-beda. Namun, terdapat kemungkinan lain yaitu adanya pemahaman masyarakat yang mengenai kanker ovarium. Pengetahuan tentang kanker ovarium faktor penting dalam pencegahan kanker ovarium. Pengetahuan hendaknya diberikan kepada Wanita Usia Subur, baik dari tenaga kesehatan atau bidan wilayah.

Berdasarkan hasil penelitian yang didapat dari kuesioner sebagian responden masih berpengatuhan kurang, yang artinya responden belum mengerti apa itu kanker ovarium mengenai pengertian, penyebab,gejala, dan stadium.

Kanker ovarium adalah salah satu kanker ginekologi yang paling sering, kanker ovarium bermestastasi dengan invasi langsung struktur
Sedangkan pengetahuan wanita usia subur sesudah diberikan penyuluhan 24 responden ( $70,58 \%$ ) dalam kategori baik, sedangkan 8 responden $(23,52 \%)$ dalam kategori cukup, dan 2 responden $(5,88 \%)$ dalam kategori kurang.

yang berdekatan dengan abdomen dan pelvis dan sel - sel yang menempatkan diri pada rongga abdomen dan pelvis. Sel - sel ini mengikuti sirkulasi alami cairan peritoneal sehingga implantasi dan pertumbuhan keganansan selanjutnya dapat timbul pada semua permukaan intraperitonoal (Price - Wilson, 2006: 1297).

Kanker ovarium adalah salah satu kanker yang menyerang organ reproduksi wanita. Banyak wanita usia subur tidak mengetahuinya terutama pada tanda gejala awal kanker ovarium, sehingga banyak kasus yang ditemukan sudah masuk pada stadium lanjut. Karena kurangnya pengenalan dan pemahaman apa saja gejala yang timbul dari penyakit kanker terutama pada alat reproduksinya.

Sumber Informasi juga merupakan faktor yang mempengaruhi pengetahuan responden. Berdasarkan tabel karakteristik berdasarkan informasi yang didapat responden menunjukkan bahwa dari 24 responden ( $70,58 \%)$ belum pernah mendapatkan informasi sama sekali sebanyak, sedangkan 6 responden $(17,64 \%)$ mendapatkan informasi lewat media masa, misalnya televisi, radio, koran, majalah.

Menurut Notoatmodjo (2003: 80), informasi merupakan sumber utama dalam meningkatkan pengetahuan, yaitu untuk meningkatkan pengetahuan dipengaruhi oleh beberapa faktor termasuk pemberian informasi.

Pemberian informasi dapat dilakukan dengan berbagai macam alat bantu seperti media cetak (koran, majalah, leaflet), media elektronik (televisi, dan radio), informasi dari teman, saudara dan tetangga serta penyuluhan oleh tenaga kesehatan ataupun kader- kader kesehatan. Kecanggihan media massa saat ini banyak memberikan manfaat apabila digunakan dengan baik. Dengan adanya media massa baik di rumah, di sekolah, maupun di tempat-tempat umum diharapkan responden dapat lebih memanfaatkan fasilitas yang ada untuk menambah pengetahuan, khususnya tentang kanker ovarium. Namun, berdasarkan hasil penelitian, kemungkinan sebagian besar 
responden kurang memanfaatkan fasilitas yang ada. Kemungkinan lain bisa disebabkan oleh pengetahuan responden yang kurang, padahal dengan adanya pengetahuan yang baik akan menjadikan responden memahami akan pentingnya mengetahui kanker ovarium yang bisa menyerang organ reproduksinya dan apa sajakah gejala dan pencegahan kanker ovarium.

Berdasarkan hasil penelitian menunjukkan bahwa mayoritas wanita usia subur dengan usia $>$ 20 tahun mempunyai pengetahuan yang baik dan cukup sebanyak 31 orang, sedangkan wanita usia subur dengan usia $<20$ tahun mayoritas mempunyai pengetahuan yang kurang yaitu sebanyak 3 orang.

Pendidikan berarti bimbingan yang diberikan seseorang terhadap perkembangan orang lain menunju kearah cita-cita tertentu yang menentukan manusia untuk berbuat dan mengisi kehidupan untuk mencapai keselamatan dan kebahagiaan. Pendidikan diperlukan untuk mendapat informasi misalnya, hal - hal ynag menunjang kesehatan sehingga dapat meningkatkan kualitas hidup (Wawan, 2010: 17).

Pendidikan juga mempengaruhi pengetahuan terutama pengetahuan tentang sistem organ reproduksi sejak dini. Dengan semakin tingginya jenjang pendidikan maka informasi terkait pengetahuan juga semakin bertambah. Dan seandainya masuk dalam kategori kurang maka bisa dengan mencari reverensi lain dari sumber manapun.

Pada penelitian ini wanita usia subur dengan pengetahuan baik yaitu sebanyak 2 orang $(5,88 \%)$ mayoritas adalah bekerja swasta dan wiraswasta, sedangkan wanita usia suber dengan pengetahuan kurang ada 13 orang $(38,2 \%)$ mayoritas bekerja sebagai buruh dan ibu rumah tangga.

Menurut Markum (1991) dalam Eko Agus (2009), manusia memerlukan suatu pekerjaan untuk dapat berkembang dan berubah. Seseorang bekerja bertujuan untuk mencapai suatu keadaan yang lebih dari pada keadaan sebelumny. Dengan bekerja seseorang dapat berbuat yang bernilai, bermanfaat dan memperoleh berbagai pengalaman.

Oleh sebab itu pekerjaan juga merupakan faktor yang mempengaruhi pengetahuan seseorang. Dengan bekerja seseorang dapat mengenal situasi sosial yang berbeda-beda, berhadapan dengan individu yang berbeda pula, serta mempunyai banyak akses dalam memperoleh informasi dan pengalaman baru.

\section{2) Pengetahuan Wanita Usia Subur Tentang Kanker Ovarium Setelah Kanker Ovarium Sesudah Diberikan Penyuluhan.}

Berdasarkan jawaban dari kuesioner yang telah dibagikan pada wanita usia subur setelah diberikan penyuluhan di RT 03 RW 04 Desa Sumengko 24 responden ( 70,58\%) dalam kategori baik, , dan 2 responden $(5,88 \%)$ dalam kategori kurang.

Penyuluhan kesehatan adalah kegiatan pendidikan kesehatan yang dilakukan dengan menyebar pesan, menanamkan keyakinan, sehingga masyarakat tidak saja sadar, tahu dan mengerti tetapi juga mau dan bisa melakukan suatu anjaran yang ada hubungan dengan kesehatan (Mahfoedz dan Eka Suryani, 2006:57)

Pengetahuan yang baik setelah diberi penyuluhan menunjukkan bahwa responden mampu mengingat suatu materi yang telah diterima sebelumnya, yang artinya mengingat kembali terhadap sesuatu yang spesifik dari seluruh materi yang telah diterima sebelumnya atau rangsangan yang telah diterima. (Notoadmodjo, 2003:57).

Penjelasan diatas dapat diketahui bahwa pengetahuan yang baik setelah diberi penyuluhan ditunjukkan pada kemampuan responden dalam mengingat suatu materi yang telah diberikan, selain itu peningkatan pengetahuan wanita usia subur setelah diberi penyuluhan juga dikarenakan responden mau memperhatikan setiap penjelasan yang diberikan penyuluh dan mampu menjawab pertanyaan seputar kanker ovarium.

Penyuluhan atau pendidikan kesehatan bertujuan untuk merubah perilaku individu, keluarga, dan masyarakat dalam membina dan memelihara perilaku hidup sehat dan lingkungan sehat, serta berperan aktif dalam upaya mewujudkan derajat kesehatan yang optimal.

Pada penelitian ini penyuluhan dilakukan dengan metode ceramah dan tanya jawab. Sebelum memberikan penyuluhan, penelitian memberikan leaflet kepada responden. Leaflet berfungsi sebagai alat publikasi atau menyebarluaskan suatu informasi, selain itu peneliti juga menggunakan lembar balik untuk 
memperjelas penyampaian materi sehingga lebih mudah diterima dan diserap oleh responden.

Salah satu manfaat alat bantu penyuluhan untuk mempermudah penerimaan informasi oleh sasaran pendidikan. Pengetahuan yang ada pada seseorang diterima melalui indra. Menurut penelitian para ahli, indra yang paling banyak menyalurkan pengetahuan ke dalam otak adalah mata. Kurang lebih $75 \%$ sampai $87 \%$ dari pengetahuan manusia diperoleh atau disalurkan melalui mata. Sedangkan $13 \%$ sampai 25\% lainnya tersalur melalui indra yang lain. Dari sini dapat disimpulkan bahwa alat -alat visual lebih mempermudah cara penyampaian dan penerimaan informasi atau bahan pendidikan.

Alat bantu juga berfungsi untuk mendorong keinginan orang untuk mengetahui, kemudian lebih mendalami, dan akhirnya mendapatkan pengertian yang lebih baik. Selain itu juga dapat membantu menegakkan pengertian yang diperoleh. Didalam menerima sesuatu yang baru, manusia mempunyai kecenderungan untuk melakukan pengertian yang telah diterima. Untuk mengatasi hal ini alat bantu akan membantu menegakkan pengetahuan - pengetahuan yang telah diterima sehingga apa yang diterima akan lebih lama tersimpan didalam ingatan (Notoatmodjo, 2007:63).

Pada penyuluhan ini informasi yang diberikan peneliti mampu diterima dengan baik oleh para responden, terbukti dengan kesediannya responden mengikuti penyuluhan sampai selesai. Sehingga apa yang sebelumnya para responden belum mengerti / mengetahuai apa itu kanker ovarium akan tahu, sehingga wanita usia subur mengetahu salah satu dari berbagai macam kanker yang bisa menyerang organ repoduksinya, dan bisa menjaga kesehatan.

Selain itu responden juga mampu memahami tentang materi tentang kanker ovarium yang telah diberikan. Hal ini sesuai dengan teori yang menyebutkan bahwa orang yang telah paham terhadap objek atau materi harus dapat menjelaskan, menyebutkan contoh, menyimpulkan, meramalkan, dan sebagainya terhadap objek yang dipelajari (Notoatmodjo, 2005:60).

Pernyataan tersebut ditunjukkan pada kemampuan responden dalam menjawab pertanyaan tentang kanker ovarium. Namun daya paham seorang responden satu dengan yang lainnya tidak sama, jawaban yang mereka pilih memang jawaban yang benar namun banyak kemungkinan, apakah responden benar- benar paham sepenuhnya atau bahkan ada responden yang menjawab pertanyaan atau kuesioner tersebut dengan cara berdiskusi dengan responden lain. Hal tersebut tidak seharusnya terjadi, karena tujuan dari penyuluhan ini adalah memang untuk membuat responden memahami dan benar- benar mengetahui tentang materi yang disampaikan.

\section{3) Perbedaan Pengetahuan Wanita Usia Subur Tentang Kanker Ovarium Sebelum dan Sesudah Diberi Penyuluhan.}

Hasil uji statistik dengan menggunakan uji wilcoxon (Wilcoxon Match Pair Test) pada 34 responden, yang dihitung dengan manual menunjukkan hasil nilai $\mathrm{Z}$ hitung sebesar 5,411 dengan tingkat kemaknaan sebesar 0,05 dan $Z$ tabel $=2,045$. Hal ini berarti nilai $\mathrm{Z}$ hitung $>\mathrm{Z}$ tabel $(5,41>2,045)$ sehingga $\mathrm{H}_{0}$ ditolak dan $\mathrm{H}_{1}$ diterima. Sehingga dapat ditarik kesimpulan bahwa ada perbedaan pengetahuan wanita usia subur tentang kanker ovarium sebelum dan sesudah diberi penyuluhan.

Adanya perbedaan pengetahuan wanita usia subur tentang kanker ovarium ditunjang oleh data khusus. Peningkatan yang signifikan yaitu dapat dilihat pada pengetahuan sebelum diberikan penyuluhan terdapat 2 responden ( 5,88 $\%$ pengetahuannya dalam katagori baik, 16 responden $(47,05 \%)$ dalam kategori cukup, dan 16 responden $(47,05 \%)$ dalam kategori kurang. Kemudian sesudah diberikan penyuluhan terdapat 24 responden ( 70,58\%) dalam kategori baik, sedangkan 8 responden $(23,52 \%)$ dalam kategori cukup, dan 2 responden $(5,88 \%)$ dalam kategori kurang.

Perbedaan pengetahuan yang tampak signifikan setelah diberikan penyuluhan memperlihatkan bahwa responden mampu menelan dan menangkap informasi yang disampaikan melalui penyuluhan tersebut. Kemampuan responden dalam menerima informasi denganbaik disebabkan beberapa faktor, salah satunya faktor dalam penelitian ini adalah pendidikan. Mayoritas responden berpendidikan SMA yang merupan tingkat 
pendidikan yang cukup tinggi untuk menjamin kemampuan responden dalam menangkap informasi lebih cepat. Selain pendidikan faktor umur responden yang didominasi kelompok 2039 tahun menjadi faktor yang juga berpengaruh dalam kemampuan responden menelan informasi yang diterima karena semakin tua umur semakin matang pula cara berpikir dan bertindak seseorang.

Bentuk penyuluhan yang dikemas secara baik dan merarik juga mempengaruhi keberhasilan dalam penyuluhan. Metode ceramah yang digunakan dalam penyuluhan, dengan bahasa yang sopa dan mudah dimengerti responden dan menyisipkan sedikit humor saat penyuluhan agar responden tidak merasa bosan. Memberikan kesempatan bertanya dan menjawab semua pertanyaan yang berkaitan dengan materi. Serta menggunakan alat bantu leaflet untuk mempermudah responden dalam menerima materi yang disampaikan. Cara - cara tersebut dapat digunakan untuk memperlancar dan membantu dalam keberhasilan penyuluhan. Sehingga tujuan dari penyuluhan dari penyuluhan itu sendiri dapat tercapai yaitu meningkatkan pengetahuan wanita usia subur tentang kanker ovarium.

\section{Simpulan}

Mengingat pentingnya peran penyuluhan kesehatan dalam meningkatkan pengetahuan, kesadaran serta perilaku kesehatan. Maka petugas kesehatan perlu memaksimalkan upaya dalam memberikan penyuluhan - penyuluhan kesehatan kepada wanita usia subur mempunyai pengetahuan yang baik, dan mampu mengatasi masalah kesehatannya secara mandiri terutama dalam hal ini adalah masalah wanita usia subur.
Hal ini berarti penyuluhan kesehatan dalam promosi kesehatan diperlukan sebagai upaya meningkatkan penegtahuan dan kesadaran, disamping sikap dan perbuatan.

Selanjutnya diharapkan dapat tercapainya tujuan penyuluhan kesehatan yang lebih luas yaitu untuk merubah perilaku kesehatan menjadi lebih baik. Perilaku kesehatan sendiri meliputi perilaku dalam pemeliharaan kesehatan yaitu usaha - usaha seseorang untuk memelihara atau menjaga kesehatan agar tidak sakit dan usaha penyembuhan baik sakit. Perilaku pencarian dan penggunaan sistem atau fasilitas pelayanan kesehatan yaitu upaya atau tindakan seseorang pada saat menderita penyakit. Perilaku kesehatan lingkungan ialah bagaimana seseorang merespon lingkungan baik lingkungan fisik maupun sosial budaya sehingga lingkungan tersebut tidak mempengaruhi kesehatannya ( Notoatmodjo, 2007: 136).

Apabila tujuan penyuluhan diatas dapat dicapai, maka jalan untuk mencapai tujuan dari pemerintah dalam bidang kesehatan semakin dekat yaitu meningkatkan derajat kesehatan masyarakat, dalam penelitian ini adalah kesehatan wanita usia subur.

Daftar Pustaka

Andria, Dita. 2010. Seluk-Beluk Kesehatan Reproduksi Wanita. Yogjakarta: A ${ }^{+}$Plus Books

Arikunto, Suharsimi. 2010. Prosedur Penelitian Suatu Pendekatan Praktik. Jakarta: PT Rineka Cipta

Suharsimi. 2006.Prosedur Penelitian

Suatu Pendekatan Praktik. Jakarta : PT Rineka Cipta

Hidayat, A. Aziz. 2007. Metode Penelitian Kebidanan Teknik Analisis Data. Jakarta : Salemba Medika 
Nining Istighosah : Perbedaan Pengetahuan Wanita Usia Subur ( WUS ) Tentang Kanker Ovarium Sebelum Dan Sesudah Diberi Penyuluhan ( Di RT 03 RT 04 Desa Sumengko Kecamatan Sukomoro Kabupaten Nganjuk )

Maharani, S. 2009. Mengenal 13 Jenis Kanker \& Pengobatannya. Yogyakarta : Katahati

Maulana, Heri D. J. 2007. Promosi Kesehatan. Jakarta: EGC

Mubarak, Wahit Iqbal. 2011. Promosi Kesehatan Untuk Kebidanan. Jakarta: Salemba Medika Notoatmodjo, Soekidjo. 2007. Promosi Kesehatan \& Ilmu Perilaku. Jakarta: PT Rineka Cipta

, Soekidjo. 2005. Metode PenelitianKesehatan. Jakarta: PT Rineka Cipta

Nursalam. 2008. Konsep \& Penerapan Metodologi Penelitian Ilmu Keperawatan. Jakarta : Salemba Medika

Prawirohardjo, Sarwono. 2011. Ilmu Kandungan. Jakarta: PT Bina Pustaka Sarwono Prawirohardjo
Price, Sylvia Anderson \& Wilson, Lorraine McCarty. 2006. Patofisiologi Konsep Klinik Proses-Proses Penyakit. Jakarta: EGC

Rasjidi, Imam.2009. Deteksi Dini Pencegahan Kanker Pada Wanita. Jakarta: Sagung Seto

Setiati, Eni. 2009. Waspada Kanker Ganas Pembunuh Wanita. Yogyakarta: ANDI

Sugiyono.2005. Metode Penelitian Administrasi. Bandung: CV. Alfabeta

Wawan, A \& M. Dewi. 2010. Pengetahuan, Sikap, dan Perilaku Manusia. Yogyakarta: Nuha Medika Wanita Usia Subur, 2013(Update 18 April 2014) Diakses dari (http://wanitaus.blogspot.com/2013/01/wanitausia-subur.html) 